\title{
DECENTRALISATION MECHANISMS OF LOCAL DEMOCRACY POLITICAL AND ADMINISTRATIVE PROCESSES WITHIN CONTEMPORARY UKRAINIAN SCIENTIFIC DISCOURSE
}

\author{
Gulay V. V., Hrynoch N. V.
}

\section{INTRODUCTION}

Over the recent years, Ukraine has been actively transitioning to a new model of territorial power organisation, based on decentralisation and the establishment of viable institutions of local self-government, namely the amalgamated hromadas, also known as the united territorial communities. There is no doubt that it is impossible to achieve a new quality of local selfgovernment without fundamental changes in approaches to comprehend the institutional and procedural principles of the local democracy political and administrative processes at the level of local self-government.

The theoretical and applied aspects of local self-government democratisation and the formation of local democracy are reflected in the works by Ukrainian political scientists, including S. Bayrak, S. Bula, M. Lendel, Y. Sadykova, M. Tsumarev and others.

A separate layer of the Ukrainian scientific bibliography on the decentralisation of political and administrative processes at the level of local self-government bodies is represented by the research works of contemporary lawyers, namely Y. Baltsii, V. Grobova and others.

Alongside with the political science and legal literature, it is appropriate to indicate the scientific results on studying political and administrative management local democracy problems by public administration specialists, including I. Arkhypenko, O. Batanov, T. Kravchenko and others.

The aim of the given study is to analyze the conditions and prospects as for the decentralisation of political and administrative processes within the context of local demoracy establishment in contemporary Ukrainian science. To achieve this goal, the following tasks are set:

- to reveal the main approaches to comprehend the "local selfgovernment" concept in Ukrainian science;

- give characteristics of the current conditions relating to the local selfgovernment system in Ukraine;

- focus on the transformation of the place and role of some local selfgovernment institutions while establishing democratic principles in the Ukrainian state; 
- consider the concepts and essential characteristics of local democracy;

- determine the main approaches to comprehend decentralisation, its forms and levels of functioning;

- prove the importance of decentralisation processes for the establishment of democratic institutions in Ukrainian society;

- indicate the positive and negative consequences resulting from the implementation of decentralisation processes in territorial communities;

- summarise proposals for enhancing the decentralisation processes and establishing new local communities.

The methodological basis of the study includes general philosophical, general logical and special scientific methods. Researching decentralisation mechanisms applied while political and managerial processes of local democracy is determined by the need for a comprehensive analysis of the topic and it is based on an integrated approach exercising historical, neoinstitutional, systemic, structural and functional, comparative and other methods.

\section{Local self-government as the component of democratic political system}

The "self-government" term can be considered within two senses. First, from a broader perspective, when a state is viewed as a self-governing organisation, and the parliament to be its integral part acts as a body of selfgovernment. Secondly, in a more narrow sense, it can be addressed as a complex legally regulated self-government institution, which includes relations not only in the field of public authority and the exercise of state power, but also relations in the sphere of population's private law interests ${ }^{1}$.

Local self-government system is an extremely complex and multidimensional social, political and legal institution, its legalisation is enshrined in the constitutional law, and its formalisation is guaranteed by civic participation ${ }^{2}$.

Local self-government should be considered as the right of a territorial community to resolve the issues of local significance independently. The right to solve one's own problems and govern one's life independently,

\footnotetext{
${ }^{1}$ Гробова В.П. Система місцевого самоврядування в Україні: проблеми теорії і практики : автореф. дис. ... доктр. юрид. н. : 12.00 .02 «Конституційне право; муніципальне право». Харківський національний університет внутрішніх справ. Харків, 2013. С. 26.

${ }^{2}$ Коваль Ю.О. Специфіка формування і розвитку національної моделі місцевого самоврядування в Україні. Політичне життя. 2016. № 3. С. 24.
} 
without external interference, is a coherent part of the human and civil rights system in a democratic society ${ }^{3}$.

The degree of self-government development depends on the degree of democracy development in a society: the more contributions to the society democratisation are implemented, the more widely its self-governing principles are developed. Consequently, it is assumed here that selfgovernment has a close connection with democracy, and it is its manifestation or the part of it represented by a specific institution as an implementation instrument ${ }^{4}$.

Municipalism to be a special mode of self-governing (municipal) power functioning provides for the priority of human and civil rights and freedoms over the interests of local self-government bodies, the limitation and selfrestraint of those authorities in favour of civil society, and it is an integral part of constitutionalism 5 .

Local self-government is characterised by some features:

- the people are its source, and its primary bearer is the territorial community;

- it applies only to the territory of administrative-territorial units (municipalities);

- its bodies function on behalf of the territorial community, not the people or the state;

- the material and financial resources of its bodies consist of communal (municipal) property and local (municipal) budget;

- its bodies have closer ties with the population;

- there is no rigid hierarchy and subordination within the system of its bodies $^{6}$.

The contradictory and inconsistent nature of democratic changes in legislative and regulatory frameworks of local self-government is on account of the specifics of democratic transition in Ukraine ${ }^{7}$.

3 Батанов О. Муніципальна влада у системі сучасного муніципалізму: концептуальні проблеми теорії. Юридичний вісник. 2010. № 3. С. 17.

4 Байрак С.О. Місцеве самоврядування - основа розвитку демократичної держави. Панорама політологічних студій. 2013. Вип. 10. С. 150.

5 Орловський О.С. Муніципалізм як складник конституціоналізму. Актуальні проблеми держави і права : зб. наук. пр. 2014. Вип. 71. С. 23.

6 Ладонько Л.С., Кудленко А.В., Михайловська О.В., Філіпова Н.В. Роль та функції місцевого самоврядування в системі публічної влади України. Теорія та практика державного управління. 2016. Вип. 4. С. 157-162. URL: http://nbuv.gov.ua/UJRN/Tpdu_2016_4_26.

7 Бортнікова А.В. Місцеве самоврядування на Волині: суспільно-політичні традиції і сучасний процес децентралізації : монографія. Луцьк : Вежа-Друк, 2018. C. 306. 
The crisis situation in local self-government institutions, which activity should have ensured the formation, development and assimilation of democratic traditions in a transitional society, on the contrary, reveals the elements of crisis as for social and political consciousness (political apathy, alienation, frustration $)^{8}$.

The establishment of the independent Ukrainian state and the democratisation processes require new approaches to the creation and development of political institutions, including local self-government institutions. To be the representative of people power, local self-government has to ensure the authorities to be in touch with the citizens, it should promote our country integration into a democratic political regime ${ }^{9}$.

At the same time, the democratisation of the political process in Ukraine, in particular at the local level, requires the introduction of some additional measures, namely the improvement of national legislation in the field of referendums and elections, the introduction of control and accountability mechanisms of elected representatives to the citizens both by revocation, recall, early termination of a mandate and by introducing the preferential voting within open party lists, etc ${ }^{10}$.

The existing system of local self-government is more appropriate considered to be a dynamic system generated by political and social conflicts of interest, which is in a permanent crisis mode being far enough from stable condition and functional excellence ${ }^{11}$.

Concurrently, the problem of local self-government development in Ukraine is the strengthening of its politicisation processes, especially within the context of local government functions' execution, which is demonstrated

8 Цумарєв М.I. Роль інститутів громадянського суспільства у формуванні культури локальної демократії громадянського типу. Регіональні студії. 2018. № 12. С. 72 .

9 Січкар О., Баштанник В.. Становлення і розвиток механізмів місцевої демократії в контексті європеїзації територіальної організації влади. Державне управління та місиеве самоврядування : зб. наук. праць. 2009. Вип. 3. URL: http://www.dbuapa.dp.ua/vidavnictvo/2009/2009-03(3)/09soktov.pdf.

10 Кавилін О.А. Політична участь як об'єкт політико-правового дослідження. Філософія і політологія в контексті сучасної культури. 2014. Вип. 8. С. 207.

11 Садикова Є.О. Інститут представництва на місця в умовах трансформації системи місцевого самоврядування в Україні : дис. ... канд. політ. н. : 23.00.02 «Політичні інститути та процеси». Д3 «Південноукраїнський національний педагогічний університет імені К.Д. Ушинського». Одеса, 2016. URL: http://www.pdpu.edu.ua/doc/vr/sadikova/dis.pdf 
by the implementation or blocking the implementation of the interests of certain social groups ${ }^{12}$.

The existing local self-government institutions are more effective when they are objectively embedded in public life, in the authority and administration system, when they are perceived as objectively valid vertical separation of powers, as the distribution of authority powers at all levels. That is to say, local self-government acts as a part of the democratic selforganisation of society, as an element of the authority and administration general structure ${ }^{13}$.

Therefore, the developed and efficient local government should become an integral part of statehood, the one that is based on the initiative of the population, its organisational and legal, functional, financial and economic independence, state support and guarantee, etc ${ }^{14}$.

Currently, local self-government efficiency is one of the key issues within the context of fast-developing political system of Ukraine. One can state the need to reform local self-government, applying international experience and adapting self-government modern models according to present-day realities ${ }^{15}$.

That is why the legal enshrinement of innovative forms of citizens' realisation of their right to participate in local self-government is considered to be relevant ${ }^{16}$.

\section{Local democracy concept}

To meet the successful modernisation of all life areas in Ukraine the country requires updating the social and political model of its development,

${ }^{12}$ Котенко Т.В. Тенденції розвитку функцій місцевого самоврядування в умовах розбудови громадянського суспільства. Часопис Київського університету права. 2012. № 1. С. 81

13 Татаренко Т.М. Організація життедіяльності територіального простору в контексті системної модернізації українського суспільства. Держава $і$ право : збірник наукових праць. Серія: Політичні науки. 2016. Вип. 71. С. 92.

14 Батанов О. Актуальні проблеми реформи конституційної моделі місцевого самоврядування в Україні. Наукові записки Інституту політичних і етнонаціональних досліджень ім. І.Ф. Кураса НАН Украӥни. 2016. Вип. 5-6 (85-86). C. 34-35.

15 Гливка А.О. Ефективність функціонування місцевого самоврядування як гарантія становлення громадянського суспільства: проблеми реформування. Держава і право : збірник наукових праць. Серія Політичні науки. Випуск 74. Ін-т держави і права ім. В.М. Корецького НАН України. Київ : Вид-во «Юридична думка», 2016. С. 133.

${ }^{16}$ Кравченко Т. Інноваційні інструменти реалізації громадянами права на участь у місцевому самоврядуванні в Україні. Публічне адміністрування: теорія та практика. 2015. Вип. 2. URL: http://nbuv.gov.ua/UJRN/Patp_2015_2_22. 
the conversion of population into influential factors, legal entities of these transformations. It might come true due to the expansion of opportunities for public participation while the state policy formation and its implementation through various forms of public social activity and self-organisation. To ensure the representation of citizens' interests in public authorities and local governments is of an extreme importance as well ${ }^{17}$.

The municipal democracy level, to be the product of local population's civic engagement, is inevitably programming the democratic political regime in the state and society ${ }^{18}$.

Until recently, instead of the term "local democracy", which is widespread in the Polish political discourse, the term "egional democracy" was mainly used in Ukraine.

M. Lendiel uses the term "regional democracy" to describe the political regime implemented at the lowest territorial level of public authority within the institutions of civil society. It is guaranteed by the state and its features are autonomy, the combination of representative and direct forms of democracy, competition of elites, democratic participation in politics, as well as the presence of favourable political and cultural vectors ${ }^{19}$.

Local democracy to be a conceptual basis for the functioning of representative and local self-government institutions is based on the concept of participatory democracy and it is closely related to the development of civil society, which provide for the citizens' participation in political life. Those processes are determined not only by the need to protect individual interests, but also by the development of a general awareness of civic unity which is considered to be a prior condition for the introduction of highquality political representation within local communities ${ }^{20}$.

The system of local democracy provides for the close relationships between citizens and authorities, the ability of citizens to be actively

${ }^{17}$ Коніщева Н., Воропаєва В. Легітимізація місцевої ініціативи як інструмент активізації органів самоорганізації населення. Громадянське суспільство Украӥни: сучасний стан і перспективи впровадження європейських стандартів взаємодї з державою : зб. матеріалів міжнар. наук.-практ. конф. (12 грудня 2013 р., м. Київ) / упоряд. В.М. Яблонський, О.А. Корнієвський, П.Ф. Вознюк; за заг. ред. О.А. Корнієвського. Київ : НІСД, 2014. С. 176.

18 Батанов О. Муніципальна влада у системі сучасного муніципалізму: концептуальні проблеми теорії. Юридичний вісник. 2010. № 3. С. 19.

19 Лендьєл М. Місцева демократія у країнах Центральної та Східної Європи Ужгород : Мистецька лінія, 2011. С. 39.

${ }^{20}$ Садикова Є.О. Інститут представництва на місця в умовах трансформації системи місцевого самоврядування в Україні : дис. ... канд. політ. н. : 23.00.02 «Політичні інститути та процеси». ДЗ «Південноукраїнський національний педагогічний університет імені К.Д. Ушинського». Одеса, 2016. URL: http://www.pdpu.edu.ua/doc/vr/sadikova/dis.pdf. 
involved in decision-making processes, to influence the agenda of local selfgovernment bodies, to create an open and responsible society. According to S. Bula, the establishment of local democracy system depends on the beneficial preconditions, the legal and regulatory framework ${ }^{21}$. It is indeed true that political values are related to the system of authority relations and political institutions. They motivate the actions of political actors, and therefore they are of pluralistic nature. Political values contain persons' ideas on the current and future political relations, the desired types of political institutions and the ways to achieve their goals ${ }^{22}$.

The task of state bodies at the local, regional and national levels is to promote the development of local democracy institutions, provide organisational and material support and encourage them to participate in making and implementation of decisions on local policy issues ${ }^{23}$.

The main purpose of the territorial power reform is to construct a decentralised model of power organisation capable in a market economy to influence effectively and efficiently the processes of social, economic and cultural development of territories. The model that would ensure a highquality level of management services provided to the population in accordance with European standards and which would be capable of selfimprovement and self-regulation ${ }^{24}$.

\section{Decentralization mechanisms of political and administrative processes. Theoretical substantiation}

The mechanism for democratic and effective local self-government establishment is decentralisation, which ensures the transfer of part of the power to self-governing institutions. The object of decentralisation is the

21 Була С. Нормативні та організаційні передумови локальної демократії в Україні. Вісник Львівського університету. Серія філософсько-політологічні студіï. 2013. Вип. 3. С. 120.

22 Дьоміна О.С. Політична культура як ціннісно-нормативна система сучасного українського суспільства. Науковий часопис Національного педагогічного університету імені М.П. Драгоманова. Серія 22: Політичні науки та методика викладання сочіально-політичних дисциилін. 2014. Вип. 15. С. 155.

${ }^{23}$ Майко Т.С. Механізми взаємодії органів місцевої влади і громади. Сучасне суспільство. 2017. Вип. 1. С. 123.

24 Січкар О., Баштанник В.. Становлення і розвиток механізмів місцевої демократії в контексті європеїзації територіальної організації влади. Державне управління та місцеве самоврядування : зб. наук. праць. 2009. Вип. 3. URL: http://www.dbuapa.dp.ua/vidavnictvo/2009/2009-03(3)/09soktov.pdf. 
community, that is a local social system and it is able to implement the management functions ${ }^{25}$.

At the present stage of state formation, there are three types of decentralisation: political, administrative and fiscal, as well as there are three major forms of decentralisation - deconcentration, devolution and delegation. Political decentralisation is firstly, the transfer of powers from central government to lower levels; secondly, joint policy development and implementation through stakeholder engagement. Political decentralisation is manifested through devolution ${ }^{26}$.

It is advisable to reduce the forms of decentralisation and their varieties to two major forms:

- unconditional and full transfer of powers as well as all sources of resource support to self-government bodies;

- transfer of responsibility for the exercise of these powers to local governments while maintaining a centralised supply of resources. And the execution of delegated power functions is due to the receipt, flow of resources from the central government ${ }^{27}$.

Ukrainian scientists claim that the process of power decentralisation has two levels, namely horizontal (delegation of powers between the branches of government) and vertical (distribution of powers between the levels of government). Therefore, given this circumstance, it is necessary to specify that local self-government is the level of government, and consequently it cannot duplicate the functions or powers of state authorities ${ }^{28}$.

The separation of local self-government as a relatively independent branch of public administration does not mean or even does not presuppose it is to be democratic, as while the absence of effective mechanisms to uphold public interests no one can exclude the use of public money or property to satisfy narrow sectional or even private interests ${ }^{29}$.

According to I. Arkhypenko, the following major decentralisation advantages should be highlighted among others: a clear delineation of

${ }^{25}$ Кубай Т.С. Місцеве самоврядування як інститут демократичного суспільства: управлінсько-правовий аспект. Ефективність державного управління. 2015. Вип. 42. С. 270.

26 Пережняк Б., Бальцій Ю. Категорія «децентралізація» в сучасному муніципалізмі: поняття та сутність. Юридичний вісник. 2018. № 3. С. 13.

${ }^{27}$ Кулішенко Т.Ю. Децентралізація державної влади: основні підходи. Вісник Донеиького національного університету імені Василя Стуса. Серія: Політичні науки. 2016. № 1. С. 19.

${ }^{28}$ Гринюк Р.Ф., Примуш М.М. Регіональний та державний виміри української специфіки децентралізації влади. Політичне життя. 2016. № 3. С. 15.

29 Мельниченко В.I. Безпосередня демократія як складова i чинник демократичного врядування в Україні. Державне управління: теорія та практика. 2013. № 2. C. 230-239. URL: http://nbuv.gov.ua/UJRN/Dutp_2013_2_28. 
powers between the executive authorities and various levels of local government; creating the preconditions for the successful development of civil society; the participation of territorial community members in solving issues of local importance; more efficient allocation of budget resources in order to address the urgent needs of the territorial community; creating favourable conditions for the development of local economy; assistance to the development of the regional economy and strategic planning; ensuring transparency and publicity of management decisions in local communities; improving the quality of services and their maximum approximation to consumers; increasing the responsibility of local bodies and local government officials for their activities to voters and the state ${ }^{30}$.

The expected results of the local self-government reform and power decentralisation in Ukraine should be mentioned, including the creation of favourable legal conditions for the widest involvement of the population in management decisions, as well as the development of direct forms of government by the people (democracy); the introduction of quality standards for public services provided to the population by local self-government bodies of the basic and regional levels, quality assessment criteria; ensuring the division of powers between local and regional self-government bodies, local state administrations and territorial bodies of central executive bodies ${ }^{31}$.

Decentralisation of power is a basic condition for establishing an effective dialogue between a community and district, district and region, region and state ${ }^{32}$.

The processes of power decentralisation and the development of local self-government have a complex dialectical connection, its essence is to provide local communities with the right to manage and to govern, but not only to form a certain level of professionalism and competence. The aforementioned in many ways causes the institutional weakness of local government to be directly controlled by public officials as carriers of high standard professionalism and competence while addressing local issues ${ }^{33}$.

${ }^{30}$ Архипенко I. Зарубіжний досвід децентралізації влади: уроки для України. Державне управління та місцеве самоврядування. 2018. Вип. 4. С. 13.

31 Крегул Ю., Батрименко В. Реформування місцевого самоврядування в Україні. Зовнішня торгівля: економіка, фінанси, право. 2016. № 1. С. 24-25.

32 Дзвінчук Д.І. Механізми демократії участі: суть та особливості застосування на місцевому рівні. Теорія та практика державного управління. 2016. Вип. 1. С. 17.

${ }_{33}$ Гринюк Р.Ф., Примуш М.М. Регіональний та державний виміри української специфіки децентралізації влади. Політичне життя. 2016. № 3. С. 15. 
The effectiveness of political processes taking place in the united territorial communities depends both on the work of local authorities and on the initiative of its residents ${ }^{34}$.

However, alongside with the positive aspects of decentralisation, there are certain shortcoming, including complications to influence the macroeconomic situation at the state level; less coordination while the implementation of delegated powers; slowing down the implementation of state programmes against the background of paying more attention to local political priorities; self-removal of central authorities from solving urgent issues; inconsistency of delegated powers and responsibilities with the resources for their implementation ${ }^{35}$.

Decentralisation of power is an obligatory segment of the democratisation process. However, it is not equivalent to democracy, since the decentralisation institution might be also one of the forms to implement cartel management, and it can be successfully used by elites to provide an environment where the democracy application is not possible ${ }^{36}$.

In this regard, it is worth referring to the article by V. Popazohlo. The author claims that political processes are influenced not only by formal, but also by informal institutions represented by a variety of destructive ones. Destructive informal institutions are the basis for the appearance ofrentoriented type of behaviour, they construct uncivilised mechanisms and algorithms of power reproduction ${ }^{37}$.

The decentralisation process should not be based on the cultural peculiarities of the region and it should not be the instrument of manipulative influence of certain political forces on the public, so as not to provoke public confrontation and separatism processes. The decentralisation process should address not only formal, but also essential and substantive characteristics. Therefore, the division into regions has to go along with the modelling democratic consciousness and national patriotism; comprehensive discussion of the regionalism problems by various public circles and the mass media participation; taking into account the dispositions and interests

34 Любиченко Н. Демократичні процеси в ході діяльності об'єднаних територіальних громад. Форум прямої демократії: матеріали доповідей та тез всеукраїнської науково-практичної конференції, Київ, 4 грудня 2018 р. / За заг. ред. Войтович Р.В., Ворони П.В. Київ : ТОВ «Видавничий дім «АртЕк»», 2019. С. 83.

35 Архипенко I. Зарубіжний досвід децентралізації влади: уроки для України. Державне управління та місиеве самоврядування. 2018. Вип. 4. С. 13.

36 Кулішенко Т.Ю. Механізм процесу інституційного оформлення децентралізації влади. Вісник Донецького нащіонального університету імені Василя Стуса. Серія: Політичні науки. 2017. № 2. С. 29-30.

${ }^{37}$ Попазогло В.С. Деструктивні неформальні політичні інститути: форми прояву та механізми протидії. Політичне життя. 2018. № 1. С. 85. 
of local communities of the basic level and on. This process should take place from the bottom to the top on a gradual and phased basis. Only under such conditions, regional political identity may become the reason and basis for decentralisation ${ }^{38}$.

The implementation of decentralisation grounds and principles is an important condition for overcoming paternalistic sentiments in a transitional society ${ }^{39}$.

Decentralisation is an important precondition for the institutionalisation of democracy in present-day Ukraine. However, it will be effective provided that the state and civil society interact to find the ways to resolve social and political conflicts in a peaceful and constructive manner ${ }^{40}$.

Decentralisation of power to be the component of regional development state policy is one of the defining ones on the reform agenda in Ukraine. It has paved the way for the establishment of fundamental institutional transformations, for enhancing citizens quality of life and it is of great importance for the continuation of sectoral reforms. Due to the appearance of a new system of power distribution between central and local authorities, a new system of relations between various branches of government and a new system of checks and balances are currently being formed in Ukraine ${ }^{41}$.

Civil society, representing a certain social community of the population, should become the main detonator of the power decentralization process; it acquires new opportunities to embody its potential in the political arena ${ }^{42}$.

The active citizens' involvement in the process of making managerial decisions at the local level is a condition for the successful implementation of the policy of state power decentralisation in Ukraine, the implementation

38 Гапоненко В.А. Децентралізація як механізм створення передумов демократизації політичної системи в Україні. Вісник Донецького національного університету імені Василя Стуса. Серія: Політичні науки. 2018. № 3. С. 57.

${ }^{39}$ Гурик М.I., Шумка М.Л. Трансформація специфічних ознак патерналізму в умовах децентралізації в Україні. Політичне життя. 2018. № 1. С. 30.

40 Гапоненко В.А. Децентралізація як механізм створення передумов демократизації політичної системи в Україні. Вісник Донеиького національного університету імені Василя Стуса. Серія: Політичні науки. 2018. № 3. С. 57.

41 Децентралізація влади: порядок денний на середньострокову перспективу. Аналітична доповідь / Жаліло Я.А., Шевченко О.В., Романова В.В. та ін. Національний інститут стратегічних досліджень. Київ. 2019. 115 с. URL: https://niss.gov.ua/sites/default/files/2019-05/2019.pdf.

42 Гройсман В.Б. Структурно-функціональна роль децентралізації влади у процесах становлення громадянського суспільства. Ефективність державного управління. 2015. Вип. 44. С. 223. 
of administrative and territorial reforms, the improvement of the local selfgovernment national institutions ${ }^{43}$.

At the same time, the implementation of a decentralised management system is a rather complex and long-term process that should be clearly and carefully defined. Decentralisation reform requires constant attention and adjustment, political and technical support from the government. It should be noted that there is still no single global model of decentralised management that could be recommended for the application in all countries ${ }^{44}$.

In Ukraine the decentralisation of power is established through the prism of two opposite models, namely the "administrative" model (direct exercise of power by local administrative bodies and the local community is only a participant of the governance process) and the "public management" one (attempts by local communities to be involved in the process of managing their own territory, to be autonomous from state interference, and it might be a certain risk in regard to the balance of power). Therefore, in Ukraine the problem of developing a "medium model" of decentralisation is becoming an extremely urgent one. It should combine highly professional officials from among local communities and it should not entail risks of separatism and authority imbalance ${ }^{45}$.

Decentralisation in Ukraine is no longer the process of coordination and cooperation between the state authorities and the local community, but a political situation where local self-government is as a necessary but optional level of power. Optionality here should be comprehended in the context of its institutional positioning. According to R. Grynyuk and M. Prymush, decentralisation of state power in Ukraine is only a mechanism and system of horizontal redistribution of powers (between branches of government), while in European and world practice it is a vertical one. In other words, the local government powers are delegated not by the executive branch, but by the government, which is a personified institution of power, and it does not have a direct right and authority while the process of delegating them to local authorities. All of the aforementioned indicates that the current

43 Законодавче врегулювання інституту місцевого референдуму в Україні: аналітична доповідь / Павленко І.А., Макаров Г.В., Токар-Остапенко О.В. Київ : НІСД, 2013. С. 5.

${ }^{44}$ Дирів А.Б. Децентралізація влади та реформування місцевого самоврядування як етап формування нової ефективної системи управління. Проблеми розвитку публічного управління в Україні : матеріали науково-практичної конференції за міжнародної участі до 100-річчя запровадження державної служби України (12-13 квітня 2018 р., м. Львів) / за наук. ред. чл.-кор. НАН України В.С. Загорського, доц. А.В. Ліпенцева. Львів : ЛРІДУ НАДУ, 2018. С. 40.

${ }^{45}$ Гринюк Р.Ф., Примуш М.М. Регіональний та державний виміри української специфіки децентралізації влади. Політичне життя. 2016. № 3. С. 15. 
situation with the decentralisation of power within the context of local selfgovernment results in the establishment of two models, namely administrative and public-civil ones ${ }^{46}$.

\section{CONCLUSIONS}

Based on the study, we can draw the following conclusions and recommendations:

1. The "local self-government" concept plays an important role in the present-day Ukrainian discourse of public administration, political science and law, as they analyze its nature, characteristics, manifestations and development trends from different points of view.

2. We can agree with our numerous Ukrainian colleagues to determine the crisis in the system of local self-government in Ukraine and, accordingly, the need to reform it, including methodological principles.

3. Based on this, the need for successful modernisation of all spheres of life in Ukraine requires updating the social and political development model. It should be emphasised that the local self-government reform should not be an end in itself, like a "reform for the sake of reform", but it should be planned and implemented in conjunction with the renewal of other fields of public life.

4. The concept of local democracy as one of the basic theoretical and methodological approaches while the process of reforming the local selfgovernment system in Ukraine should be considered.

5. Decentralisation is an important precondition for the democracy institutionalisation in present-day Ukraine.

6 . We can agree that the main purpose of transforming the territorial power organisational system in Ukraine should be the construction of a decentralised model, capable to influence effectively and efficiently the processes of social, economic and cultural development under conditions of market economy.

7. The mechanism for the democratic and effective local self-government establishment is decentralisation, which ensures the delegation of a part of powers to self-governing structures.

8. At the present stage of Ukrainian state formation, three types of decentralisation are being implemented, namely political, administrative and fiscal, as well as three main forms of decentralisation, that is deconcentration, devolution and delegation.

9. The expected results of local self-government reform and decentralisation of power in Ukraine should result in the creation of

${ }^{46}$ Гринюк Р.Ф., Примуш М.М. Регіональний та державний виміри української специфіки децентралізації влади. Політичне життя. 2016. № 3. С. 14. 
favourable legal conditions for the widest involvement of the population in management decisions at the level of local self-government bodies.

10. Alongside with the positive achievements of the decentralisation process at the current stage of the transformation of public power territorial organisation, the researchers are right when pointing out the negative manifestations of the decentralisation processes, which require adequate response to minimise risks for the Ukrainian state as a whole.

\section{SUMMARY}

The aim of the given study is to analyze the conditions and prospects as for researching the decentralisation of political and administrative processes within the context of local democracy establishment in contemporary Ukrainian science.

In accordance with the set goal the actual tasks have been solved and they are summerised in the conclusions of the work. The main approaches to comprehend the concept of "local self-government" in Ukrainian science have been revealed. The current position of the local self-government system in Ukraine is described. Considerable attention is paid to the transformation of the place and role of some local self-government institutions while establishing the democratic foundations for the Ukrainian state. The concept and essential characteristics of local democracy have been considered. The main approaches to comprehend decentralisation, its forms and levels of functioning have been identified and described. The essential importance of decentralisation processes for the democratic institutions' establishment in Ukrainian society has been proved. The positive and negative consequences related to the implementation of the decentralisation course in Ukraine are pointed out. The proposals on the intensification of decentralisation processes and establishment of new local communities have been generalised.

\section{REFERENCES}

1. Архипенко I. Зарубіжний досвід децентралізації влади: уроки для України. Державне управління та місиеве самоврядування : збірник наукових праць. 2018. Вип. 4. С. 7-15.

2. Байрак С.О. Місцеве самоврядування - основа розвитку демократичної держави. Панорама політологічних студій. 2013. Вип. 10. С. 148-154.

3. Батанов О. Актуальні проблеми реформи конституційної моделі місцевого самоврядування в Україні. Наукові записки Інституту політичних $і$ етнонаціональних досліджень ім. І.Ф. Кураса НАН України. 2016. Вип. 5-6. С. 34-42. 
4. Батанов О. Муніципальна влада у системі сучасного муніципалізму: концептуальні проблеми теорії. Юридичний вісник. 2010. № 3. C. 16-22.

5. Бортнікова А.В. Місцеве самоврядування на Волині: суспільнополітичні традиції і сучасний процес децентралізації : монографія. Луцьк : Вежа-Друк, 2018. 372 с.

6. Була С. Нормативні та організаційні передумови локальної демократії в Україні. Вісник Львівського університету. Серія філософсько-політологічні студіі. 2013. Вип. 3. С. 119-129.

7. Гапоненко В.А. Децентралізація як механізм створення передумов демократизації політичної системи в Україні. Вісник Донеиького нащіонального університету імені Василя Стуса. Серія: Політичні науки. 2018. № 3. С. 54-58.

8. Гливка А.О. Ефективність функціонування місцевого самоврядування як гарантія становлення громадянського суспільства: проблеми реформування. Держава і право : збірник наукових праць. Серія: Політичні науки. 2016. Вип. 74. С. 132-141.

9. Гринюк Р. Ф., Примуш М.М. Регіональний та державний виміри української специфіки децентралізації влади. Політичне життя. 2016. № 3. C. 12-17.

10.Гробова В.П. Система місцевого самоврядування в Україні: проблеми теорії і практики : автореф. дис. ... доктр. юрид. н. : 12.00 .02 «Конституційне право; муніципальне право». Харківський національний університет внутрішніх справ. Харків, 2013. 38 с.

11. Гройсман В.Б. Структурно-функціональна роль децентралізації влади у процесах становлення громадянського суспільства. Ефективність державного управління. 2015. Вип. 44. С. 221-229.

12.Гурик М.І., Шумка М.Л. Трансформація специфічних ознак патерналізму в умовах децентралізації в Україні. Політичне життя. 2018. № 1. С. 26-32.

13. Децентралізація влади: порядок денний на середньострокову перспективу : аналітична доповідь / Жаліло Я.А., Шевченко О.В., Романова В.В. та ін. Національний інститут стратегічних досліджень. Київ. 2019. 115 с. $\quad$ URL: https://niss.gov.ua/sites/default/files/201905/2019.pdf.

14. Дзвінчук Д.І. Механізми демократії участі: суть та особливості застосування на місцевому рівні. Теорія та практика державного управління. 2016. Вип. 1. С. 14-22.

15. Дирів А.Б. Децентралізація влади та реформування місцевого самоврядування як етап формування нової ефективної системи управління. Проблеми розвитку публічного управління в Україні : матеріали науково-практичної конференції за міжнародної участі до 
100-річчя запровадження державної служби України (12-13 квітня 2018 р., м. Львів) / за наук. ред. чл.-кор. НАН України В.С. Загорського, доц. А.В. Ліпенцева. Львів : ЛРІДУ НАДУ, 2018. С. 39-41.

16. Дьоміна О.С. Політична культура як ціннісно-нормативна система сучасного українського суспільства. Науковий часопис Національного педагогічного університету імені М.П. Драгоманова. Серія 22: Політичні науки та методика викладання сочіальнополітичних дисииплін. 2014. Вип. 15. С. 148-155.

17.Законодавче врегулювання інституту місцевого референдуму в Україні: аналітична доповідь / Павленко I.А., Макаров Г.В., ТокарОстапенко О.В. Київ : НІСД, 2013. 42 с.

18. Кавилін О.А. Політична участь як об'єкт політико-правового дослідження. Філософія $і$ політологія в контексті сучасної культури. 2014. Вип. 8. С. 204-208.

19. Коваль Ю.О. Специфіка формування і розвитку національної моделі місцевого самоврядування в Україні. Політичне життя. 2016. № 3. C. 24-31.

20. Коніщева Н., Воропаєва В. Легітимізація місцевої ініціативи як інструмент активізації органів самоорганізації населення. Громадянське суспільство Украӥни: сучасний стан $i$ перспективи впровадження європейських стандартів взаємодії з державою : зб. матеріалів міжнар. наук.-практ. конф. (12 грудня 2013 р., м. Київ) / упоряд. В.М. Яблонський, О.А. Корнієвський, П.Ф. Вознюк; за заг. ред. О.А. Корнієвського. Київ : НІСД, 2014. С. 167-172.

21.Котенко Т.В. Тенденції розвитку функцій місцевого самоврядування в умовах розбудови громадянського суспільства. Часопис Київського університету права. 2012. № 1. С. 80-84.

22. Крегул Ю., Батрименко В. Реформування місцевого самоврядування в Україні. Зовнішня торгівля: економіка, фінанси, право. 2016. № 1. С. 17-27.

23. Кравченко Т. Інноваційні інструменти реалізації громадянами права на участь у місцевому самоврядуванні в Україні. Публічне адміністрування: теорія та практика. 2015. Вип. 2. URL: http://nbuv.gov.ua/UJRN/Patp_2015_2_22.

24. Кубай T.Є. Місцеве самоврядування як інститут демократичного суспільства: управлінсько-правовий аспект. Ефективність державного управління. 2015. Вип. 42. С. 266-273.

25. Кулішенко Т.Ю. Децентралізація державної влади: основні підходи. Вісник Донецького національного університету імені Василя Стуса. Серія: Політичні науки. 2016. № 1. С. 17-20.

26. Кулішенко Т.Ю. Механізм процесу інституційного оформлення децентралізації влади. Вісник Донецького національного університету імені Василя Стуса. Серія: Політичні науки. 2017. № 2. С. 27-30. 
27. Ладонько Л.С., Кудленко А.В., Михайловська О.В., Філіпова Н.В. Роль та функції місцевого самоврядування в системі публічної влади України. Теорія та практика державного управління. 2016. Вип. 4. C. 157-162. URL: http://nbuv.gov.ua/UJRN/Tpdu_2016_4_26.

28. Лендьєл М. Місцева демократія у країнах Центральної та Східної Європи. Ужгород : Мистецька лінія, 2011. 688 с.

29. Любиченко Н. Демократичні процеси в ході діяльності об'єднаних територіальних громад. Форум прямої демократії : матеріали доповідей та тез всеукраїнської науково-практичної конференції, Київ, 4 грудня 2018 р. / За заг. ред. Войтович Р.В., Ворони П.В. Київ : ТОВ «Видавничий дім «АртЕк»», 2019. С. 82-84.

30. Майко Т.С. Механізми взаємодії органів місцевої влади і громади. Сучасне суспільство. 2017. Вип. 1. С. 118-130.

31. Мельниченко В.I. Безпосередня демократія як складник і чинник демократичного врядування в Україні. Державне управління: теорія та практика. 2013. № 2. C. 230-239. URL: http://nbuv.gov.ua/ UJRN/Dutp_2013_2_28.

32. Орловський О.С. Муніципалізм як складник конституціоналізму. Актуальні проблеми держави і права : зб. наук. пр. 2014. Вип. 71. C. 20-25.

33. Пережняк Б., Бальцій Ю. Категорія «децентралізація» в сучасному муніципалізмі: поняття та сутність. Юридичний вісник. 2018. № 3. C. 11-16.

34. Попазогло В.С. Деструктивні неформальні політичні інститути: форми прояву та механізми протидії. Політичне життя. 2018. № 1. C. $85-90$.

35. Садикова Є.О. Інститут представництва на місця в умовах трансформації системи місцевого самоврядування в Україні : дис. ... канд. політ. н. : 23.00 .02 «Політичні інститути та процеси». Д3 «Південноукраїнський національний педагогічний університет імені К.Д. Ушинського». Одеса, 2016. URL: http://www.pdpu.edu.ua/doc/vr/sadikova/dis.pdf.

36. Січкар О., Баштанник В. Становлення i розвиток механізмів місцевої демократії в контексті європеїзації територіальної організації влади. Державне управління та місиеве самоврядування : зб. наук. праць. $2009 . \quad$ Вип. $3 . \quad$ URL: http://www.dbuapa.dp.ua/vidavnictvo/2009/2009-03(3)/09soktov.pdf.

37. Татаренко Т.М. Організація життєдіяльності територіального простору в контексті системної модернізації українського суспільства. Держава і право : збірник наукових праць. Серія: Політичні науки. 2016. Вип. 71. С. 89-104. 
38. Цумарєв M.I. Роль інститутів громадянського суспільства у формуванні культури локальної демократії громадянського типу. Регіональні студіï. 2018. № 12. С. 72-77.

Information about the authors:

Gulay V. V.,

Doctor of Political Sciences, Professor, Head of International Information Department Lviv Polytechnic National University 12, Stepana Bandery str., Lviv, 79000, Ukraine

Hrynoch N. V.,

Ph.D. in History, Associate Professor, Deputy Director for Academic Affairs of the Separated Subdivision Lviv Branch of the Kyiv National University of Culture and Arts 5, Kushevycha str., Lviv, 79000, Ukraine 